\title{
SOME FACTORS AFFECTING TWINNING RATE AND ITS EFFECTS ON POSTPARTUM REPRODUCTIVE PERFORMANCE OF FRIESIAN COWS
}

\author{
Sh.M. Shamiah, A.A. Shitta and H.M.A. Gaafar \\ Animal Production Research Institute, Agricultural Research Center, Dokki, Giza, \\ Egypt
}

\section{SUMMARY}

A total number of 1243 records of calving cases of 585 dairy Friesian cows during 8 consecutive years from 1997 to 2004 collected from Sakha Animal Production Research Station belonging to Animal Production Research Institute, Agriculture Research Center were used to study the effect of sire, live body weight (LBW) and age of dam and calving season on twinning rate and its consequent effects on postpartum reproductive performance of dairy Friesian cows.

Results indicated that, the average of twinning rate was $4.67 \%$ and freemartin rate was $0.64 \%$. Sire, live body weight, age of dam and calving season had significant $(P<0.05)$ effects on twinning rate. Twinning rate increased significantly $(P<0.05)$ with increasing live body weight and age of dams. Winter season significantly showed the lowest $(P<0.05)$ twinning rate $(3.76 \%)$ and autumn season had the highest rate (6.20\%).

Twins calving affected significantly $(P<0.05)$ all the reproductive performance under consideration except the period from calving to the first service and gestation period. In this respect, the service period, days open and calving interval were longer, number of services per conception was higher, while conception rate was lower for twins compared with single calving. The percentages of retained placenta, dystocia, abortion and born death calf were significantly $(P<0.05)$ higher with twins calving compared to single calving.

These results indicated that, several factors (genetic and environmental) affected on twinning rate in dairy Friesian cows. Calving interval for cows calved single or twins was in rate accepted, while retained placenta, dystocia, abortion and born death calf were nearly duplicate in cows calved twins compared to that of single calving.

Keywords: Friesian, twins calving, reproductive performance

\section{INTRODUCTION}

Twinning has many negative effects on some reproductive and productive aspects including increased dystocia, retained placenta, longer rebreeding intervals, higher mortality rates, frequent occurrence of freemartins (sterile females) (Beerepoot et al., 1992; and Nielen et al., 1989) and reduced and (or) delayed conception after twinning (Turman et al., 1971; and Gregory et al., 1990b). One would anticipate a preference for selection against twinning. However, individuals with high twinning rates still appear, especially in the Holstein breed, which ranged from 1.6 to $8.8 \%$ (Rutledge,

Issued by The Egyptian Society of Animal Production 
1975). Day et al. (1995) reported that California Holstein cows gave $6.86 \%$ of birth twins. Eddy et al. (1991) observed twinning rate in British dairy cattle was $2.5 \%$ and increased with parity $(0.9 \%$ for first parity up to $5 \%$ by sixth parity). Nielen et al. (1989) observed a 3.2\% twinning rate in Dutch Friesians and Holsteins. Protection of recessive alleles may explain the repeated occurrence of high twinning individuals. However, Van Vleck and Gregory (1996) reported no dominance effects for ovulation rate, a trait closely related to twinning rate. Gregory et al. (1990a) concluded that twinning rate is a quantitative trait that has an underlying continuous expression involving many loci.

Although repeatability was not estimated, Nielen et al. (1989) noted a tendency of twinning cows to twins again from cows that had twinned once and twice, 9.3 and $12.5 \%$, respectively. It should be noted that these values were higher than expected. Assuming that 6.4 and $3.3 \%$ from cows twinned once and twice would be expected to twins again. Ron et al. (1990) reported the twinning rate in Israel Holsteins to be 4.8 and $6.9 \%$ for second and third parity cows, respectively. The twinning rate of Israel Holsteins has increased from 4.5 to $5.6 \%$ during the last 20 year. In general, twinning reduced the reproductive performance of dams in their subsequent pregnancy and in the case of freemartins reduced the calves reproductive performance as well (Beerepoot et al., 1992; and Eddy et al., 1991).

The objective of this study was to evaluate the effect of sire, live body weight and age of dams and calving season on twinning rate and its effects on reproductive problems and postpartum reproductive performance of dairy Friesian cows.

\section{MATERIALS AND METHODS} Experimental animals:

A total number of 1243 records of calving cases of 585 dairy Friesian cows during the consecutive 8 years from 1997 to 2004 collected from Sakha Animal Production Research Station belonging to Animal Production Research Institute, Agriculture Research Center, Ministry of Agriculture. All cows ranged between 350-650 kg live body weight, $3-13$ years of age and 1-8 parities.

\section{Feeding and management:}

Animal were housed in semi open sheds and fed traditional summer ration consisted of concentrate feed mixture, berseem hay, rice straw with or without corn silage and winter ration consisted of concentrate feed mixture, fresh berseem and rice straw. Cows were fed according to requirements of Animal Production Research Institute Recommendation (1997). They were fed in-group feeding assigned according to live body weight, age, milk yield and reproductive status. Concentrate feed mixture and rice straw were offered two times daily, while fresh berseem, berseem hay or corn silage were offered once daily. Water was available for animals all the day round. Cows were artificially inseminated using frozen semen within 14 hours after onset of the first spontaneously occurring estrus and number of service per conception were recorded.

\section{Collected data:}

The collected data included sires, live body weight and age of dams, season of calving, type of birth (single or twins) for the different years. Also, the periods from parturition to first service, concepts service, service period, days open, gestation 
period, calving interval, number of services per conception, conception rate, incidence of retained placenta, dystocia, abortion and born death calf were recorded.

\section{Statistical analysis:}

The obtained data was statistically analyzed using general linear models procedure adapted by SPSS for windows (2004) for user's guide. Duncan test within program SPSS was done to determine the degree of significance between means. The model was as follows:

Where:

$$
\mathrm{Y}_{\mathrm{ijxL}}=\mathrm{u}+\mathrm{S}_{\mathrm{i}}+\mathrm{DW}_{\mathrm{j}}+\mathrm{DA}_{\mathrm{x}}+\mathrm{CS}_{\mathrm{L}}+\mathrm{e}_{\mathrm{ijxL}}
$$

$\mathrm{Y}_{\mathrm{ijxL}}=$ The observation $\mathrm{i}$ jxl of the trait.

$\mathrm{U}=$ The overall mean

$\mathrm{S}_{\mathrm{i}} \quad=$ Fixed effect of the $\mathrm{i}^{\text {th }}$ sire.

$\mathrm{DW}_{\mathrm{j}}=$ Fixed effect of the $\mathrm{j}^{\text {th }}$ dam weight.

$\mathrm{DA}_{\mathrm{x}}=$ Fixed effect of the $\mathrm{x}^{\text {th }}$ dam age.

$\mathrm{CS}_{\mathrm{L}}=$ Fixed effect of the $\mathrm{Lx}^{\text {th }}$ calving season.

$\mathrm{e}_{\mathrm{ijxL}} \quad=$ The random error associated with individual record of the ijxL observation.

\section{RESULTS AND DISCUSSION}

\section{Some factors affecting twinning rate: Sire:}

The effects of sire on twinning rate in dairy Friesian cows are presented in Table (1). The heritability of twinning rate in Friesian cows was 0.028 , which were within the values obtaine by Gregory et al. (1990a) who found that heritability of twinning rate in cows was $0.02 \pm 0.07$. Data collected over eight years showed that the average twinning rate in dairy Friesian cows was $4.67 \%$ and the percentage of freemartin from total number of cows and twin calving were 0.64 and $13.80 \%$, respectively. Eddy et al. (1991) observed that twinning rate in British dairy cattle was 2.5\%. But, Day et al. (1995) found it $6.86 \%$ in California Holstein cows.

The differences in twinning rate among the different sires were significant $(\mathrm{P}<0.01)$, with ranged from 0.00 to $9.38 \%$. The linear regression coefficient of twinning rate on sire was significant $(0.061)$. While, Rutledge (1975) reported that twinning rate in the Holstein breed ranged from 1.6 to $8.8 \%$. Differences among sire groups indicate some genetic change is occurring in the population. The increased incidence of twins in recent years could be an indication of a correlated response to selection for increased milk yield. Ron et al. (1990) reported that increased twinning rate was correlated with increased milk yield in Israeli Holsteins.

\section{Live body weight of dams:}

Data in Table (2) reveal that live body weight of dams had a significant $(\mathrm{P}<0.05)$ effect on twinning rate in dairy Friesian cows. The highest twinning rate $6.67 \%$ was observed in cows having higher live body weight (LBW) between $600-650 \mathrm{~kg}$, while, the lowest rate $2.08 \%$ was found for cows having LBW between $350-400 \mathrm{~kg}$.

It means that the twinning rate increased significantly $(\mathrm{P}<0.05)$ with increasing the dam weight. Cows weighed 550-600 kg expressed the highest freemartin rate being $2 \%$. The linear regression coefficient of twinning rate on cows weight was significant (0.045). These results indicated that, increased LBW is associated with a good feeding level and may consequently increase ovulation rate that closely associated with 
twinning rate. Van Vleck and Gregory (1996) reported that body weight of dams had dominance effects for ovulation rate, which closely related to twinning rate.

Table 1. Effect of sire on twinning and freemartin rates in dairy Friesian cows

\begin{tabular}{cccccc}
\hline \multirow{2}{*}{ Sire no. } & $\begin{array}{c}\text { No. } \\
\text { of records }\end{array}$ & \multicolumn{2}{c}{ Twins calving } & \multicolumn{2}{c}{ Freemartin } \\
& 132 & 9 & Rate $\%^{2}$ & N & Rate \% \\
\hline 1 & 62 & 4 & $6.82^{\mathrm{ab}}$ & 0 & 0.00 \\
2 & 32 & 3 & $9.45^{\mathrm{b}}$ & 1 & 1.61 \\
3 & 75 & 6 & $8.38^{\mathrm{a}}$ & 0 & 0.00 \\
4 & 310 & 20 & $6.45^{\mathrm{ab}}$ & 2 & 2.70 \\
5 & 138 & 10 & $7.25^{\mathrm{ab}}$ & 3 & 0.97 \\
6 & 77 & 6 & $7.79^{\mathrm{ab}}$ & 0 & 1.45 \\
7 & 417 & 0 & $0.00^{\mathrm{c}}$ & 0 & 0.00 \\
Others & 1243 & 58 & 4.67 & 8 & 0.00 \\
\hline Total & & 5 & & 0.64 \\
\hline
\end{tabular}

$\mathrm{a}$ and $\mathrm{b}$ : Means in the same column with different superscripts differ significantly $(\mathrm{P}<0.05)$.

Table 2. Effect of live body weight of dams on twinning and freemartin rates in dairy Friesian cows

\begin{tabular}{|c|c|c|c|c|c|}
\hline \multirow{2}{*}{$\begin{array}{c}\text { Live body } \\
\text { weight } \\
\text { (kg) }\end{array}$} & \multirow{2}{*}{$\begin{array}{c}\text { No. } \\
\text { of records }\end{array}$} & \multicolumn{2}{|c|}{ Twins calving } & \multicolumn{2}{|c|}{ Freemartin } \\
\hline & & $\mathbf{N}$ & Rate \% & $\mathbf{N}$ & Rate \% \\
\hline $351-400$ & 48 & 1 & $2.08^{\mathrm{d}}$ & 0 & 0.00 \\
\hline $401-450$ & 151 & 6 & $3.97^{\mathrm{cd}}$ & 0 & 0.00 \\
\hline $451-500$ & 426 & 18 & $4.23^{\mathrm{bc}}$ & 2 & 0.47 \\
\hline $501-550$ & 393 & 19 & $4.83^{b c}$ & 2 & 0.51 \\
\hline $551-600$ & 150 & 9 & $6.00^{\mathrm{ab}}$ & 3 & 2.00 \\
\hline $601-650$ & 75 & 5 & $6.67^{\mathrm{a}}$ & 1 & 1.33 \\
\hline Total & 1243 & 58 & 4.67 & 8 & 0.64 \\
\hline
\end{tabular}

$\mathrm{a}, \mathrm{b}, \mathrm{c}$ and $\mathrm{d}$ : Means in the same column with different superscripts differ significantly $(\mathrm{P}<0.05)$.

\section{Age of dams:}

The effect of age of dams on twinning rate of dairy Friesian cows is shown in Table (3). Twinning rate increased significantly $(\mathrm{P}<0.05)$ with advancing age, which ranged from $3.97 \%$ for cows aged $3-5$ years to $13.64 \%$ for cows aged $11-13$ years. While cows aged 9-11 years showed significantly $(\mathrm{P}<0.05)$ the highest freemartin rate being $5.55 \%$. The linear regression coefficient of twinning rate on age of dams was significant (0.037). These results are in agreement with those obtained by Echternkamp and Gregory (1999), who found that twinning rate increased with the advance of dam's age. 
Table 3. Effect of age of dams on twinning and freemartin rates in dairy Friesian cows

\begin{tabular}{|c|c|c|c|c|c|}
\hline \multirow{2}{*}{$\begin{array}{c}\text { Age } \\
\text { (Year) }\end{array}$} & \multirow{2}{*}{$\begin{array}{c}\text { No. } \\
\text { of records }\end{array}$} & \multicolumn{2}{|c|}{ Twins calving } & \multicolumn{2}{|c|}{ Freemartin } \\
\hline & & $\mathbf{N}$ & Rate \% & $\mathbf{N}$ & Rate \% \\
\hline $3-5$ & 706 & 28 & $3.97 \mathrm{~b}$ & 1 & $0.14^{\mathrm{b}}$ \\
\hline $5-7$ & 302 & 14 & $4.64 \mathrm{ab}$ & 3 & $0.99^{\mathrm{b}}$ \\
\hline $7-9$ & 177 & 10 & $5.65 \mathrm{ab}$ & 2 & $1.13^{\mathrm{b}}$ \\
\hline $9-11$ & 36 & 3 & $8.33 \mathrm{ab}$ & 2 & $5.55^{\mathrm{a}}$ \\
\hline $11-13$ & 22 & 3 & $13.64 \mathrm{a}$ & 0 & $0.00^{\mathrm{b}}$ \\
\hline Total & 1243 & 58 & 4.67 & 8 & 0.64 \\
\hline
\end{tabular}

\section{Calving season:}

The effects of calving season on twinning rate in dairy Friesian cows are shown in Table (4). The twinning rate differs significantly $(\mathrm{P}<0.05)$ among the different seasons. In this regard, autumn season showed the highest rate $(6.20 \%)$ and winter season had the lowest rate $(3.76 \%)$. Twinning rate was $5.22 \%$, during the summer season and $4.18 \%$ during season. The rate of freemartin tended to be higher in autumn season $(1.55 \%)$ compared with the other calving seasons. This results is accordance with those reported by (Gregory et al., 1990a), who found that the effects of season on twinning rate were different in beef cattle under seasonal breeding programs. It is noticeable that the percentage of twins from total twins calving in (winter and summer) was $27.6 \%$ and in (spring and autumn) was $22.4 \%$. The incidence of freemartin rate in summer season was $1.55 \%$ being higher than that in other seasons.

Table 4. Effect of calving season on twinning and freemartin rates in Friesian cows

\begin{tabular}{cccccc}
\hline $\begin{array}{c}\text { Age } \\
\text { (Year) }\end{array}$ & $\begin{array}{c}\text { No. } \\
\text { of records }\end{array}$ & \multicolumn{2}{c}{ Twins calving } & \multicolumn{2}{c}{ Freemartin } \\
\cline { 3 - 6 } Winter & 425 & 16 & Rate \% & N & Rate \% \\
Spring & 311 & 13 & $4.16^{\mathrm{c}}$ & 2 & 0.47 \\
Summer & 249 & 13 & $5.22^{\mathrm{ab}}$ & 1 & 0.32 \\
Autumn & 258 & 16 & $6.20^{\mathrm{a}}$ & 4 & 0.40 \\
\hline Total & 1243 & 58 & 4.67 & 8 & 0.64 \\
\hline a, b and c: Means in the same column with different superscripts differ significantly $(\mathrm{P}<0.05)$.
\end{tabular}

\section{Effect of twinning on postpartum reproductive performance: Reproductive periods:}

The effects of twinning on reproductive performance in dairy Friesian cows are shown in Table (5). The service period, days open and calving intervals were significantly $(\mathrm{P}<0.05)$ longer after twins calving compared to single calving. The periods from parturition to first service, service period, days open and calving interval after twins calving increased by $3.54,14.32,17.86$ and 17.78 day than single calving, respectively. The linear regression coefficients of the period from parturition to first service, service period, days open, gestation period and calving interval on twins calving were $0.100,0.087,0.071,0.003$ and 0.071 , respectively. A longer interval from parturition to first ovulation or conception in dams of twins vs. singles is well documented (Turman et al., 1971; Cady and Van Vleck, 1978; Wheeler et al., 1982; 
and Guerra-Martinez et al., 1990). Such delays may result from longer uterine involution period after twins calving. Additional suckling and lactation stress were also suggested by Bellows et al. (1974). In this concept weaning the calves soon after birth removed such negative effect of twins calving on postpartum estrus (Bellows et al., 1974). Turman et al. (1971) demonstrated that early weaning enhanced conception.

Table 5. Effect of twinning on reproductive performance and milk yield of dairy Friesian cows

\begin{tabular}{lccc}
\multicolumn{1}{c}{ Traits } & Single calving & Twins calving & SEM \\
\hline Reproductive periods: & & & \\
- First service (day) & 45.87 & 49.41 & 0.51 \\
- Service period (day) & $67.62^{\mathrm{b}}$ & $81.94^{\mathrm{a}}$ & 2.62 \\
- Days open (day) & $113.49^{\mathrm{b}}$ & $131.35^{\mathrm{a}}$ & 2.56 \\
- Gestation period (day) & 277.41 & 277.3 & 0.22 \\
- Calving interval (day) & $390.87^{\mathrm{b}}$ & $408.65^{\mathrm{a}}$ & 2.56 \\
\hline Conception rates \%: & & & \\
- Entire first 90 day of lactation & $35.78^{\mathrm{a}}$ & $22.41^{\mathrm{b}}$ & 1.35 \\
- Entire first 120 day of lactation & $46.50^{\mathrm{a}}$ & $34.48^{\mathrm{b}}$ & 1.41 \\
- Entire first 150 day of lactation & $54.77^{\mathrm{a}}$ & $41.38^{\mathrm{b}}$ & 1.41 \\
- Entire lactation & $72.83^{\mathrm{a}}$ & $62.07^{\mathrm{b}}$ & 1.27 \\
\hline No. of service per conception & $2.70^{\mathrm{b}}$ & $3.18^{\mathrm{a}}$ & 0.06 \\
\hline Reproductive problems: & & & \\
- Retained placenta \% & & $37.93^{\mathrm{a}}$ & 1.23 \\
- Dystocia \% & $24.22^{\mathrm{b}}$ & $15.52^{\mathrm{a}}$ & 0.72 \\
- Abortion \% & $6.50^{\mathrm{b}}$ & $5.17^{\mathrm{a}}$ & 0.28 \\
- Born death calf \% & $2.87^{\mathrm{b}}$ & $1.72^{\mathrm{a}}$ & 0.01 \\
\hline a and b: Means in the same row with different superscripts differ significantly (P<0.05).
\end{tabular}

\section{Conception rates and number of service per conception:}

The conception rates entire the first 90, 120, 150 day and lactation were significantly $(\mathrm{P}<0.05)$ higher, and the number of service per conception was significantly $(\mathrm{P}<0.05)$ lower for single compared with twins calving $(35.78,46.50$, 54.77 and 72.83 , Vs. $22.41,34.48,41.38$ and $62.07 \%$, respectively) as shown in Table (5). The linear regression coefficients of conception rates entire the first 90, 120, 150 and lactation and number of service per conception on twinning calving were 0.060 , $0.048,0.048,0.051$ and 0.051 , respectively. The reduction in fertility occurred primarily in dams of twins. Twins has many negative effects on reproduction, which reduced and (or) delayed conception after twinning calving (Turman et al., 1971; and Gregory et al., 1990b).

\section{Reproductive problems:}

Results in Table (5) showed that the average percentages of retained placenta, dystocia, abortion and born death calf in twins birth cows were significantly $(\mathrm{P}<0.05)$ higher than those birth single $(37.93,15.5,5.17$ and 1.72 vs. 24.22, 6.50, 2.87 and 0.93 respectively). The linear regression coefficients of the percentages of retained placenta, dystocia, portion and born death calf on twinning calving were $0.067,0.075$, 
0.029 and 0.017 , respectively. These results agreed with those obtained by Echternkamp and Gregory (1999) who found that the majority of the retained placenta was associated with twins births. Previous findings by Chew et al. (1977) suggested that the retained placenta resulted from physiological immaturity of the placenta (i.e., decreased estradiol-17b and increased progesterone synthesis) at parturition, which presumably would be more prevalent in twins births with the shorter gestation length. Similarly, twins calves are smaller and physiologically less mature at birth (Gregory et al., 1990b, \&1996). Dystocia with single births in cattle is generally associated with larger physical size and (or) birth weight and (or) with small or young dams (Bellows et al., 1971; and Gregory et al., 1990b, \& 1996). Dystocia with twins resulted primarily (i.e., $78.9 \%$ of the dystocia) from abnormal presentation of head and (or) legs for one or both twins fetuses at parturition. The increased incidence of fetal membrane presentation with twins may result from the higher circulating concentrations of progesterone and estradiol found in cows gestating multiple fetuses (Echternkamp, 1992).

\section{CONCLUSION}

In conclusion, sire, body weight and age of dams and season of calving showed significant effect on twinning rate, which had adverse effect on reproductive performance of Friesian cows.

\section{REFERENCES}

Animal Production Research Institute, 1997. Animal Nutrition Scientifically and Practically. $1^{\text {st }}$ Ed. Animal Production Research Institute, Agricultural Research Center, Ministry of Agriculture, Dokki, Giza, Egypt (In Arabic).

Beerepoot, G.M.M., A.A. Dykhuizen; M. Nielen and Y.H. Schukken, 1992. The economics of naturally occurring twinning in dairy cattle. J. Anim. Sci., 75: 1044.

Bellows, R.A., R.E. Short; D.C. Anderson; B.W. Knapp and O.F. Pahnish, 1971. Cause and effect relationships associated with calving difficulty and calf birth weight. J. Anim. Sci., 33: 407.

Bellows, R.A., R.E. Short, J.J. Urick and O.F. Pahnish, 1974. Effects of early weaning on postpartum reproduction of the dam and growth of calves born as multiples or singles. J. Anim. Sci., 39: 589.

Cady, R.A. and L.D. Van Vleck, 1978. Factors affecting twinning and effects of twinning in Holstein dairy cattle. J. Anim. Sci., 46: 950.

Chew, B.P., H.F. Keller, R.E. Erb and P.V. Malven, 1977. Periparturient concentrations of prolactin, progesterone and the estrogens in blood plasma of cows retaining and not retaining fetal membranes. J. Anim. Sci., 44: 1055.

Day, J.D., L.D. Weaver and C.E. Franti, 1995. Twins pregnancy diagnosis in Holstein cows: Discriminatory powers and accuracy of diagnosis by trans rectal palpation and outcome of twin pregnancies. Can. Vet. J., 36: 93.

Echternkamp, S.E., 1992. Fetal development in cattle with multiple ovulations. J. Anim. Sci., 70: 2309.

Echternkamp, S.E. and K.E. Gregory, 1999. Effects of twinning on gestation length, retained placenta, and dystocia. J. Anim. Sci., 77: 39. 
Eddy, R.G., O. Davies and C. David, 1991. An economic assessment of twin births in British dairy herds. Vet. Rec., 129: 526.

Gregory, K.E., S.E. Echternkamp and L.V. Cundiff, 1996. Effects of winning on dystocia, calf survival, calf growth, carcass traits, and cow productivity. J. Anim. Sci., 74: 1223.

Gregory, K.E., S.E. Echternkamp; G.E. Dickerson; L.V. Cundiff; R.M. Koch and L.D. Van Vleck, 1990b. Twinning in cattle: III. Effects of twinning on dystocia, reproductive traits, calf survival, calf growth and cow productivity. J. Anim. Sci., 68: 3133 .

Gregory, K.E., S.E. Echternkamp, G.E. Dickerson, R.M. Koch and L.D. Van Vleck, 1990a. Twinning in cattle I: Foundation animals and genetic and environmental effects on twinning rate. J. Anim. Sci., 68: 1867.

Guerra-Martinez, P., G.E. Dickerson, G.B. Anderson and R.D. Green, 1990. Embryotransfer twinning and performance efficiency in beef production. J. Anim. Sci., 68 : 4039.

Johanson, J.M., P.J. Berger, B.W. Kirkpatrick and M.R. Dentine, 2001. Twinning Rates for North American Holstein Sires1. J. Dairy Sci., 84: 2081.

Kirkpatrick, B.W., 2002. Management of twinning cow herds. J. Anim. Sci. 80: (E. Suppl. 2): E14-E18.

Nielen, M., Y.H. Schukken, D.T. Scholl, H.J. Wilbrink and A. Brand, 1989. Twinning in dairy cattle: A study of risk factors and effects. Theriogenology, 32: 845.

Ron, M.; E. Ezra and J.I. Weller, 1990. Genetic analysis of twinning rate in Israeli Holstein cattle. Genet. Sel. Evol., 22: 349.

Rutledge, J.J., 1975. Twinning in cattle. J. Anim. Sci., 40: 803.

SPSS for windows, 2004. Statistical package for the social sciences, Release 13, SPSS INC, Chicago, USA.

Turman, E.J., D.B. Laster; R.E. Renbarger and D.F. Stephens, 1971. Multiple births in beef cows treated with equine gonadotropin (PMS) and chorionic gonadotropin (HCG). J. Anim. Sci., 32: 962.

Van Vleck, L.D. and K.E. Gregory, 1996. Variances of additive and dominance genetic effects for ovulation and twinning rates in a population selected for twinning. J. Anim. Sci., 74: 1234.

Wheeler, M.B., G.B. Anderson; R.H. BonDurant and G.H. Stabenfeldt, 1982. Postpartum ovarian function and fertility in beef cattle that produce twins. J. Anim. Sci., 54: 589. 
بعض العوامل المؤثرة على معدل التوائم وتأثيره على الأداء التناسلى بعد الولادة فى الأبقار الفريزيان العوان

شريف مغاورى شامية، عبدالستار عبدالعزيز شتا، حامد محمد عبدالمجيد جعفر

معهُ بحوث الإتتاج الحيوانى، مركز البحوث الزراعية، الدقى، الجيزة

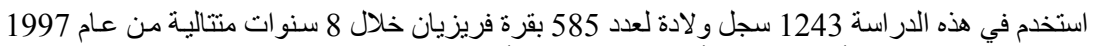

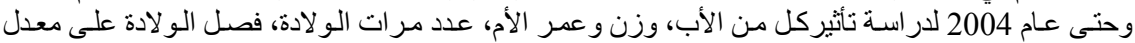

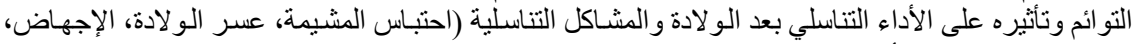
و لادة جنين نافق) في الأبقار الفريزيان.

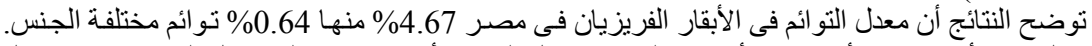

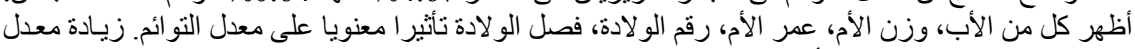

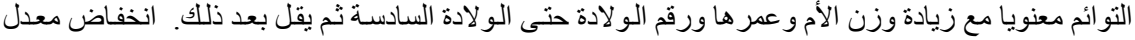

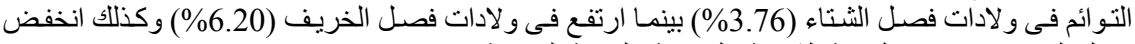

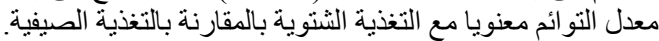

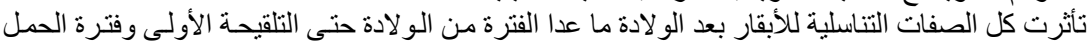

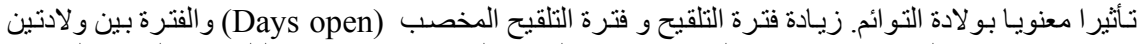

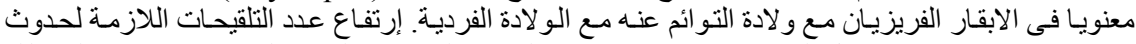

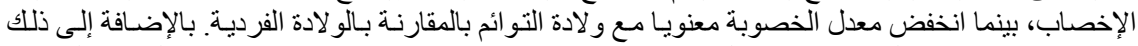

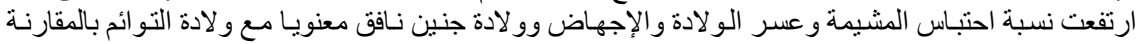

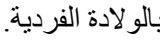
نستخلص من هذه الدراسة أن الأب، وزن وعمر الأم وموسم الو لادة لها تأثير معنوى على معدل التو ائم الذى لألى له نأثير سلبى على الأداء التناسلى للأبقار الفريزيان. 